\title{
DE SEÑAS DE IDENTIDAD A MAKBARA ESTRATEGIA NARRATIVA EN LAS NOVELAS DE JUAN GOYTISOLO
}

MARYELLEN BIEDER

Por

Indiana University

En su estudio de la poética, Jonathan Culler hace notar que "en la mayoría de los casos podemos ordenar un texto como el discurso de un narrador explícito o implícito que nos cuenta acontecimientos en un mundo". ${ }^{1}$ La "nueva novela" de las últimas décadas no siempre nos ofrece una entrada tan fácil en su mundo como la que postula Culler, y hasta puede decirse que las dificultades encontradas por el lector en muchas "nuevas novelas" se deben precisamente a la falta de una vía de comunicación claramente marcada entre texto y lector. Desde las primeras novelas de Alain Robbe-Grillet han cobrado una importancia central en discusiones críticas las cuestiones del origen del texto y la identidad del narrador. Volviendo otra vez al libro de Culler, recordemos el papel que otorga a la identificación del narrador en el acto de leer: "la identificación del narrador es una de las maneras fundamentales de naturalizar la ficción", de hacerla accesible al lector. ${ }^{2}$ Pero si falta el narrador, ¿cómo logra el lector determinar la posición que deba adoptar con relación al texto? ¿Cómo identifica el papel, implícito en el texto, que deba asumir para llevar a cabo las funciones de lector ideal? Al comentar una "nueva novela", Culler escribe: "Si pudiéramos leer [la novela] como la presentación de una situación, real o imaginaria, por parte de un narrador, ya estaríamos en vías de organizarla". ${ }^{3}$ El peligro en esta necesidad de identificar a un narrador para poder producir una lectura coherente es, desde luego, la tentación de presuponer la existencia de un narrador cuando ningún narrador proyecta su presencia dentro de la narración. Por lo tanto, se debe suponer que exista otra estrategia interpretativa aplicable a aquellos textos en que no

\footnotetext{
' Jonathan Culler, Structuralist Poetics: Structuralism, Linguistics and the Study of Literature (Ithaca: Cornell Univ. Press, 1975), p. 195; las traducciones de las citas de Culler son de Metzidakis.

2 Culler, p. 200.

${ }^{3}$ Culler, p. 194.
} 
hay narrador que presente su historia a un público explícito o implícito. Pere Gimferrer hace referencia al nuevo tipo de relación entre texto y lector que produce la ausencia de la mediación cuando habla de "un arquitecto literario de nuevo tipo-el voyeur, el intruso, el lector". ${ }^{4}$

Aunque en el sentido más estricto de la palabra el narrador es el que relata una historia a un público, por extensión caben narradores que escriben sus narraciones y cuyos destinatarios son lectores en vez de oyentes, y narradores que crean sus historias en su mente como historias que se cuentan a sí mismos. ${ }^{5}$ La mediación puede ocurrir, por lo tanto, en textos que representan discursos orales, escritos o mentales. Es posible también admitir la posibilidad de textos sin mediación alguna, textos que Chatman denomina "mínimamente narrados" o "no narrados", localizándolos en un extremo de un espectro que empieza con "narradores manifiestos" y pasa por "narradores disimulados". ${ }^{6}$

Ya hemos comentado la tendencia natural del lector a iniciar la lectura de un texto en busca de guía, sea éste un narrador de carne y hueso o una voz narrativa, que defina y delimite la perspectiva desde la cual fluye el discurso y que establezca el papel del lector en relación con la narración. Implícita en esta busca de narrador es la identificación del receptor de la comunicación al nivel del discurso, es decir, del narratee. ${ }^{7}$ Cuando el narratee toma cuerpo como personaje dentro del texto, el autor implícito tiene a su diposición un vehículo por el cual puede guiar al lector en su reacción al texto y comunicarle también la visión del mundo del autor. (Como en el caso del narrador y el lector implícito, no hace falta que coincida la perspectiva del narratee con la del autor implícito.) Sin la presencia de un narratee, se le hace más difícil al lector colocarse dentro del proceso de comunicación. Ausente el narrador, puede que el lector se sienta totalmente abandonado, especialmente si el Weltanschauung de la novela dista bastante del suyo. Un texto aparentemente no mediado exige grandes esfuerzos por parte del lector común. Como ha observado Culler con respecto a La Jalousie de Robbe-Grillet: "Las novelas se vuelven problemáticas cuando no se percibe la voz de la lectura... y por

\footnotetext{
${ }_{4}^{4}$ Juan Goytisolo cita a Gimferrer en su ensayo sobre Terra Nostra en Disidencias (Barcelona: Seix Barral, 1977), p. 246.

${ }^{5}$ Seymour Chatman discute L'Étranger de Albert Camus en términos parecidos, consideránd olo un relato en primera persona que no evoca a ningún narratee ya que Meursault, al hablar, sólo se comunica consigo mismo; Story and Discourse: Narrative Structure in Fiction and Film (Ithaca, Cornell Univ. Press, 1975), p. 261.

${ }^{6}$ Chatman, pp. 146-147.

${ }^{7}$ Chatman (p. 150) atribuye a Gerald Prince la creación del término narratee en su artículo "Notes Toward a Categorization of Fictional 'Narratees'”, Genre, 4, (1971), 100-105.
} 
consiguiente resulta imposible organizar el texto como una comunicación entre un yo implícito y un tú implícito". ${ }^{8}$ Con la desaparición del narrador/ personaje que relata su historia en voz propia a un público identificable (narratee/personaje), el concepto del narrador ha cobrado mayor complejidad. Si aceptamos, como lectores metidos en el proceso de la lectura, que es del todo imposible soslayar la cuestión de la fuente del texto entre manos con citar al "autor real", entonces la identificación del narrador (o el reconocimiento de su ausencia) viene a ser una preocupación central del lector. Al irse poniendo los textos cada vez más autorreferentes y herméticos, la tarea del lector cobra aún más importancia. En este contexto la identificación del narrador ya no es un fin en sí sino "una importante estrategia interpretativa" que, al establecer desde el principio la relación entre el lect or y el discurso, da lugar a que entre el lector en el texto. ${ }^{9}$

A pesar del torrente de "nuevas novelas" que experimentan con sus posibilidades, pocas teorías de la narración dedican mucha atención a la narración en segunda persona. Al encerrar el remitente y el receptor, el narrador y el narratee dentro del marco del pronombre único $t u$, se crea un acto de comunicación circular que permite intercambiar los papeles de remitente y receptor. La unificación de narrador y narratee intensifica la relación entre lector y narrador y simplifica el acceso de aquél al discurso narrativo. Con las últimas cuatro novelas de Juan Goytisolo como modelos, me propongo examinar la estrategia narrativa a fin de determinar hasta qué punto funciona el narrador como mediador entre lector y texto y cuáles son las implicaciones de esta mediación para el lector.

En sus novelas más recientes Juan Goytisolo se ha ido alejando cada vez más de las formas tradicionales del discurso y de la estructura narrativos, al elaborar textos a cual más autorreferentes y estructuralmente complejos que desafían las habilidades del lector medio y que niegan su plena realización a todo lector salvo el más persistente. A partir de la gama completa de pronombres personales con que experimenta en Señas de identidad, Goytisolo llega a adoptar la narración en segunda persona como la forma predominante en sus dos/siguientes novelas, con algunas incursiones limitadas en otras voces narrativas. Su última novela Makbara señala una vuelta a la interacción de perspectivas narrativas y la reafirmación de la narración en primera persona con sus connotaciones de afirmación y proyección de sí. La narración en primera persona no desapareció totalmente de las novelas intermedias, ni al nivel de la narración que pone marco al texto ni al de las que se encajan en ella. Para citar un solo ejemplo, Don Julián se abre con la

${ }^{8}$ Culler, p. 196.

${ }^{9}$ La frase es de Culler, p. 202. 
afirmación: "tierra ingrata, entre todas espuria y mezquina, jamás volverá a ti". ${ }^{10} \mathrm{El}$ acto y el momento de narración cobran una importancia central en Señas de identidad, una importancia que disminuye en las últimas novelas al volverse menos finito el momento de creación narrativa y al convertirse el narrador en una figura menos real, menos histórica. Sin embargo el acto enunciativo sigue siendo la clave principal para la identificación de la fuente de la narración, sea ésta oral, mental o escrita, y sigue sirviéndole al lector de guía al mundo del texto, especialmente cuando el narrador abandona su tradicional ropaje narrativo para convertirse, en palabras de Goytisolo, en "personaje lingüístico." El narrador manifiesto, personalizado, histórico de Señas de identidad cede primero a la presencia intemporal del narrador de Don Julián, luego a la imaginación creadora del narrador/escritor disimulado de Juan sin Tierra ${ }^{12}$ y finalmente al narrador proteico de Makbara, novela que se cierra con un capítulo sin narrador visible.

En la trayectoria narrativa de estas cuatro obras de Juan Goytisolo, el narrador de carne y hueso situado en un tiempo histórico y un espacio geográfico, el de Señas de identidad, pasa después al foco interiorizado de Don Julián, enmarcado en términos geográficos aunque no históricos y sin trabas mentales. El narrador de Juan sin Tierra abandona la convención de la narración mental a favor de la narración escrita: el narrador genera el texto que se lee en el momento de su creación. Actuand o como titiritero, delimitado por el tiempo y el espacio en el plano narrativo pero con plena libertad para la creación de un universo ilimitado, el narrador/escritor de Juan sin Tierra abandona al final del texto su medio de comunicación con el lect or, la lengua española. No es de extrañar, entonces, que el narrador de Makbara sea un contador de historias árabe, un transformacionista verbal ante un público árabe, entre el que se sitúa forzosamente el lector. El narrador desaparece como tal del último capítulo de la novela, dejando al lector con la tarea de

10 Reivindicación del conde don Julián (México: Joaquín Mortiz, 1970), p. 11.

1 Disidencias, p. 235.

12 En un artículo reciente sobre la trilogía de Goytisolo, Robert Spires caracteriza la relación entre narrador y lenguaje como una transformación en términos atañederos a la transformación narrativa de que se trata aquí. Escribe Spires: "El periplo que empezó con Señas de identidad y con la búsqueda de identidad, y que fue intensificada en Reivindicación del conde don Julián donde el narrador aniquiló su identidad biológica-cultural, ha llegado a un punto culminante en Juan sin Tierra donde la identidad personal del narrador está grabada indeleblemente en el sistema de signos internos del que él es tanto cread or como creación"; "Latrines, Whirlpools, and Voids: The Metafictional Mode of Juan sin Tierra, Hispanic Review, 48 (1980), 166-167. La tesis de Spires de que el narrador de esta última novela crea y es a la vez creado por su texto a poya la observación que el narrador se funde con el narratee. 
confrontar un texto que no revela mediación aparente y en el que vuelve a aparecer el mismo contador de historias dentro de la descripción en tercera persona.

Todas estas novelas son narraciones conscientemente construidas ya que están elaboradas por sus respectivos narradores como meditaciones sobre el proceso creador a la vez que actos creativos/recreativos. Las cuatro incorporan a la narración la interpretación de la mis ma por medio de modelos de lectura negativos, desde "las Voces" en Señas de identidad hasta las múltiples manifestaciones de Vosk en Juan sin Tierra y el conflictivo contrapunto de las "hipótesis sobre un avernícola" en Makbara. Juan sin Tierra, en particular, puede leerse como historia ejemplar de las que inducen al lector a desconfiar de los caminos falsos. Las cuatro contienen también múltiples niveles de narración, con narradores secundarios y terciarios que se dirigen a sus respectivos narratees. A partir de Juan sin Tierra el contexto de la visión narrativa ya no se establece desde el principio, y el texto considerado como producto de un narrador/escritor o un narrador/contador no se aclara hasta después de que haya iniciado el lector una lectura provisional del texto.

En Señas de identidad, mediante el uso de la narración en segunda persona, Alvaro Mendiola proyecta y distancia su identidad, dándose así la oportunidad de examinar su propia vida desde dentro pero como si estuviera fuera de ella. Nace en esta novela la alternación entre tú y él, entre el presente de la narración y el Alvaro del pasado. En Don Julián el narrador "anónimo", habiéndose roto el vínculo con su propio ser histórico-cultural, ya no está delimitado por la realidad histórica sino libre para crear su propio espacio y tiempo desde el Tánger actual. Predomina la narración en segunda persona en que se combinan la introspección, la enajenación y una honda división entre pensamiento y cuerpo.

Con Juan sin Tierra el narrador/personaje desaparece por completo al ir descartando uno por uno el narrador "rostro, nombre, familia, costumbres, tierra" y por último lengua. ${ }^{13}$ Purgada de las señales externas de su identidad, la voz narrativa se convierte en el acto creador puro, ubicado espacial (una mesa de cocina de París) y temporalmente (el mes de agosto) en el plano narrativo y acorralada únicamente por los límites de la imaginación. Al deshacerse el narrador/escritor de la identidad, la historia y la cultura propias, elude tanto la convención de la "realidad ficticia" como la de la inmutable realidad de los personajes ficticios. El escritor proclama los pronombres narrativos yo y $t u ́$ "pronombres apersonales, moldes substantivos vacíos", puesto que con un plumazo los puede crear, cambiar o destruir

${ }^{13}$ Juan sin Tierra (Barcelona: Seix Barral, 1975), p. 83. En adelante las páginas se incluirán entre paréntesis en el texto. 
(p. 158). Ha desaparecido la relación fija y estable entre creador y creación, entre narrador y narratee, al imponer el narrador/ escritor de Juan sin Tierra a su antojo el "dictado de mis voces proteicas, cambiantes". La ficción de un personaje autónomo cede al "murmullo de un vago e inidentificable discurso: ni voz mía siquiera", como se queja la voz sin cuerpo de un personaje anterior, "sino de usted, de mi amo" (p. 307). Así el narrador/escritor controla las creaciones de su pluma, subordinándolas a su realidad.

Con Makbara parece desvanecerse del todo el narrador/creador del discurso. Predomina en esta novela el recurso de pronombres cambiables utilizado de una manera limitada en las dos novelas anteriores. La perspectiva del capítulo inicial ya no es la de un narrador (uno que piensa, escribe o habla) sino la de un focalisateur, es decir, uno que ve. ${ }^{14}$ En Don Julián la alternación entre yo, tú y él proyectaba la imagen que el narrador tenía de sí en relación al pasado, presente y futuro. En Makbara los múltiples pronombres narrativos trazan el desplazamiento del foco, pero la cuestión de quién manipula el foco no se aclara hasta el final del cuerpo principal de la novela. El foco cambia constantemente en gran parte de la novela, yuxtaponiendo pronombres de tercera, segunda y primera personas y sus correspondientes formas verbales. El movimiento va desde un foco impersonal exterior, a la identificación de observador y observado, y después a un foco subjetivo interior. El lector ve al focalisée primero desde una perspectiva impersonal en tercera persona, luego une su perspectiva a la del personaje, y finalmente las perspectivas de focalisée y focalisateur se funden en la segunda persona. Las formas verbales se reemplazan continuamente también, de modo que se desplaza la distancia entre focalisateur y experiencia, a la vez que entre narración y lector. Liberados de un contenido fijo e incambiable y de las exigencias del "realismo" desde Don Julián, los pronombres se desplazan en Makbara con una facilidad sorprendente que abarca una figura desde todas las perspectivas y desde distancias cambiables:

al fin la dudosa extremidad emerge con la cautela de un resucitado abandonando las tinieblas de la tumba, esboza, tocada de súbita gracia, el ademán de tomar la hoja, pero cambia de opinión, la alza con rabia avasalladora, la plantas en medio de su mejilla, le doy una sonora bofetada ${ }^{15}$

Partiendo de una existencia al parecer autónoma, la mano llega a asociarse con una voluntad subjetivizada primero por el $t u ́$ y luego absorbida en el yo. Al final del primer capítulo de la novela, esta voz se concretiza en la

\footnotetext{
${ }^{14}$ La palabra es de Mieke Bal, "Narration et focalisation: Pour une théorie des instances du récit", Poétique, No. 29 (1977), pp. 107-127.

15 Makbara (Barcelona: Seix Barral, 1980), p. 18. En adelante las páginas se incluirán entre paréntesis en el texto.
} 
perspectiva del yo, adquiriendo un contexto y un destino. El enfoque en movimiento constante de la secuencia inicial se detiene finalmente en el narrador en primera persona localizado en un cine de París al que ha huido para librarse del contacto con las masas urbanas y para dar rienda suelta a su imaginación, dejándola volar por espacios y tiempos en recreación de su propio mundo, al igual que la película que ofrece una existencia alternativa a los espectadores. A solas consigo mismo el narrador recobra su identidad, vinculada íntimamente al tema repetido de "camino del mercado" (pp. 22, 102)

En una entrevista en 1977 Juan Goytisolo habló de la evolución constante de su concepto de discurso narrativo y de la novela que llegaría a ser Makbara:

no insistiré en el empleo del sistema coloquial, discursivo; esto es, en el recurso a la segunda persona gramatical, como he hecho casi exclusivamente desde las páginas finales de Señas de identidad. Si vuelvo a escribir será tal vez a partir de un nuevo sincretismo creador... buscando el medio de superar el esquema historia/discurso de Benveniste. ${ }^{16}$

Este nuevo "sincretismo creador" es evidente en la manera en que el focalisateur de Makbara alternativamente observa, penetra y se hace el objeto de la narración. Este sincretismo brota del narrador principal de la novela, una figura que sólo aparece al final del cuerpo central del texto. A este punto la narración exige del lector una repentina refundición del discurso como narración oral, concretamente como las historias contadas al público en el zoco por el halaiqui nesrani, el contador de historias cristiano, que ahora confiesa a todos ser el que "les ha referido la acción, asumiendo por turno voces y papeles, haciéndoles volar de uno a otro continente sin haberme movido un instante del corro fraternal que formamos" (p. 200). ${ }^{17}$ Hombro a hombro con los narratees de la halca, "este minúsculo islote de libertad y fiesta en un océano de inquidad y pobreza"(p. 200), que se escapa hacia el mundo de la historia del halaiqui, el lector descubre la clave del discurso narrativo al identificar la voz del narrador principal, el que pone marco al texto. Los narradores previos se revelan como subordinados a éste, y sus narraciones como encajadas en las historias del contador. A su vez el halaiquí, como Scheherazade, existe en virtud de las historias que cuenta-"vivir, literalmente, del cuento" (p. 219), el cuento de nunca acabar. Estas historias, que forman la narración que el lector tiene en sus manos, transcripción de las palabras en la plaza del mercado, tejen su magia y entrampan a los oyentes/lectores en "su sutil, invisible cárcel verbal" (p. 220). Del abandono

16 "Desde Juan sin Tierra", Espiral/ Revista, 2 (1977): Juan sin Tierra, pp. 10-11.

${ }^{17}$ Sólo ha aparecido una vez antes en esta novela la figura del halaiquí, habiéndose incluido entre los oyentes inesperados que aprovechan la traducción simultánea de los comentarios del guía de turismo en Pittsburgh (p. 121). 
de la lengua española a favor del árabe al final de Juan sin Tierra, Juan Goytisolo ha pasado en Makbara a una narración contada en árabe por un árabe cristianizado $\mathrm{y}$, consecuentemente, a la contemplación de la cultura occidental ya no por un español enajenado sino por un hombre a horcajadas entre ambas culturas, un hombre que recita en la lengua de una cultura pero que se ha formado en la religión de la otra.

Makbara se cierra con un capítulo que cae fuera del marco narrativo del resto de la novela, capítulo desde el cual se puede contemplar la narración enmarcada. Este último capítulo vio la luz por primera vez como texto autónomo bajo el mismo título que lleva en Makbara, "Lectura del espacio en Xemaá-El-Fná". ${ }^{18}$ La actividad constante en el zoco lo convierte en palimpsesto que se escribe y vuelve a escribirse, como las historias contadas y vueltas a contar por el halaiquí. No hay narrador identificable de este texto, no hay mano que escribe. Han desaparecido las voces narrativas de los primeros capítulos, subordinadas todas a su creador, el halaiqui, y éste se ha convertido de sujeto en objeto (p. 214). Sin embargo, un ojo parece observar el zoco, una voz anónima parece narrar desde una perspectiva mínimamente definible e identificable sólo como la de un forastero. Ningún marco define un tiempo y espacio narrativos. Las palabras ya no comunican la expresión de una perspectiva individual sino que captan la realidad en todo su movimiento. En las palabras del texto el resultado es "la plaza entera abreviada en un libro, cuya lectura suplanta la realidad” (p. 222). Guiado solamente por la más mínima mediación, el lector confronta la descripción de Xemaá-El-Fná como la realidad y tiene la sensación de establecer contacto directo con un mundo nuevo y desconocido, el de la medina.

La trayectoria narrativa en estas cuatro novelas de Goytisolo pasa de un narrador identificado y nombrado a narradores cada vez menos visibles y más absorbidos por su discurso, narradores cuya identidad cede a las múltiples transformaciones que experimentan en sus narraciones. Al punto final de esta trayectoria surge una nueva forma de narración desprovista de pronombres personales y narradores transformacionistas: un texto en que la realidad, y no el narrador, cambia constantemente de forma en una recombinación infinita de sus elementos, un texto que el lector tiene que confrontar directamente aunque sin perder nunca de vista la perspectiva disimulada y los valores implícitos en él.

Traducción de Philip Metzidakis

${ }^{18}$ Espiral/ Revista, 4 (n.d.): Avances, pp. 131-155. 